\title{
Origin and fate of the secondary nitrite maximum in the Arabian Sea
}

\author{
P. Lam ${ }^{1}$, M. M. Jensen ${ }^{1, *}$, A. Kock ${ }^{2}$, K. A. Lettmann ${ }^{3}$, Y. Plancherel ${ }^{4}$, G. Lavik ${ }^{1}$, H. W. Bange ${ }^{2}$, and \\ M. M. M. Kuypers ${ }^{1}$ \\ ${ }^{1}$ Max Planck Institute for Marine Microbiology, Celsiusstrasse 1, 28359 Bremen, Germany \\ ${ }^{2}$ Forschungsbereich Marine Biogeochemie, IFM-GEOMAR, Leibniz-Institut für Meereswissenschaften, \\ Düsternbrooker Weg 20, 24105 Kiel, Germany \\ ${ }^{3}$ Institut für Chemie und Biologie des Meeres, Carl von Ossietzky Universität Oldenburg, Carl-von-Ossietzky-Str. 9-11, \\ 26111 Oldenburg, Germany \\ ${ }^{4}$ Department of Geosciences, Guyot Hall, Princeton University, Princeton, NJ 08540, USA \\ * current address: Nordic Center for Earth Evolution (NordCEE) and Institute of Biology, University of Southern \\ Denmark, Campusvej 55, 5230 Odense M, Denmark
}

Received: 19 February 2011 - Published in Biogeosciences Discuss.: 7 March 2011

Revised: 3 June 2011 - Accepted: 8 June 2011 - Published: 20 June 2011

\begin{abstract}
The Arabian Sea harbours one of the three major oxygen minimum zones (OMZs) in the world's oceans, and it alone is estimated to account for $\sim 10-20 \%$ of global oceanic nitrogen $(\mathrm{N})$ loss. While actual rate measurements have been few, the consistently high accumulation of nitrite $\left(\mathrm{NO}_{2}^{-}\right)$coinciding with suboxic conditions in the central-northeastern part of the Arabian Sea has led to the general belief that this is the region where active $\mathrm{N}$-loss takes place. Most subsequent field studies on N-loss have thus been drawn almost exclusively to the central-NE. However, a recent study measured only low to undetectable $\mathrm{N}$-loss activities in this region, compared to orders of magnitude higher rates measured towards the Omani Shelf where little $\mathrm{NO}_{2}^{-}$accumulated (Jensen et al., 2011). In this paper, we further explore this discrepancy by comparing the $\mathrm{NO}_{2}^{-}$-producing and consuming processes, and examining the relationship between the overall $\mathrm{NO}_{2}^{-}$balance and active $\mathrm{N}$-loss in the Arabian Sea. Based on a combination of ${ }^{15} \mathrm{~N}$-incubation experiments, functional gene expression analyses, nutrient profiling and flux modeling, our results showed that $\mathrm{NO}_{2}^{-}$accumulated in the centralNE Arabian Sea due to a net production via primarily active nitrate $\left(\mathrm{NO}_{3}^{-}\right)$reduction and to a certain extent ammonia oxidation. Meanwhile, $\mathrm{NO}_{2}^{-}$consumption via anammox, denitrification and dissimilatory nitrate/nitrite reduction to ammonium $\left(\mathrm{NH}_{4}^{+}\right)$were hardly detectable in this region, though some loss to $\mathrm{NO}_{2}^{-}$oxidation was predicted from modeled $\mathrm{NO}_{3}^{-}$changes. No significant correlation was found between
\end{abstract}

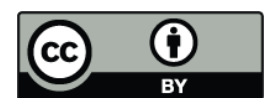

Correspondence to: P. Lam (plam@mpi-bremen.de)
$\mathrm{NO}_{2}^{-}$and $\mathrm{N}$-loss rates $(p>0.05)$. This discrepancy between $\mathrm{NO}_{2}^{-}$accumulation and lack of active N-loss in the centralNE Arabian Sea is best explained by the deficiency of labile organic matter that is directly needed for further $\mathrm{NO}_{2}^{-}$reduction to $\mathrm{N}_{2} \mathrm{O}, \mathrm{N}_{2}$ and $\mathrm{NH}_{4}^{+}$, and indirectly for the remineralized $\mathrm{NH}_{4}^{+}$required by anammox. Altogether, our data do not support the long-held view that $\mathrm{NO}_{2}^{-}$accumulation is a direct activity indicator of N-loss in the Arabian Sea or other OMZs. Instead, $\mathrm{NO}_{2}^{-}$accumulation more likely corresponds to long-term integrated $\mathrm{N}$-loss that has passed the prime of high and/or consistent in situ activities.

\section{Introduction}

In global oceans, $\mathrm{NO}_{2}^{-}$is the least abundant of the major inorganic nitrogen ions $\left(\mathrm{NH}_{4}^{+}, \mathrm{NO}_{2}^{-}, \mathrm{NO}_{3}^{-}\right)$, representing only $<0.025 \%$ of the $6.6 \times 10^{5} \mathrm{Tg} \mathrm{N}$ global oceanic inventory of fixed nitrogen (Gruber, 2008). At the second highest oxidation state $(+\mathrm{III})$ of nitrogen, $\mathrm{NO}_{2}^{-}$often occurs as an intermediate in either oxidative or reductive pathways of the $\mathrm{N}$-cycle. It can be produced during the first step of nitrification, when specific groups of archaea or bacteria oxidize ammonia to $\mathrm{NO}_{2}^{-}$, most of which is then oxidized by a separate group of bacteria to $\mathrm{NO}_{3}^{-}$. In the reductive pathways, $\mathrm{NO}_{2}^{-}$is produced via nitrate reduction, which may further lead to the production of gaseous nitrous oxide $\left(\mathrm{N}_{2} \mathrm{O}\right)$ and dinitrogen $\left(\mathrm{N}_{2}\right)$, in the stepwise $\mathrm{N}$-loss process known as denitrification $\left(\mathrm{NO}_{3}^{-} \rightarrow \mathrm{NO}_{2}^{-} \rightarrow \mathrm{NO} \rightarrow \mathrm{N}_{2} \mathrm{O} \rightarrow \mathrm{N}_{2}\right)$. Denitrification can occur heterotrophically or autotrophically, but the former is presumably more common in seawater. $\mathrm{NO}_{2}^{-}$

Published by Copernicus Publications on behalf of the European Geosciences Union. 
may also be channeled through another $\mathrm{N}$-loss process called anammox (van de Graaf et al., 1995), in which some autotrophic bacteria use $\mathrm{NO}_{2}^{-}$to anaerobically oxidize ammonium $\left(\mathrm{NH}_{4}^{+}\right.$) to $\mathrm{N}_{2}$. Alternatively, $\mathrm{NO}_{2}^{-}$may be reduced directly to $\mathrm{NH}_{4}^{+}$in dissimilatory nitrate/nitrite reduction to ammonium (DNRA).

Though often barely detectable in seawater, $\mathrm{NO}_{2}^{-}$can accumulate to micromolar concentrations at the base of the sunlit euphotic zone due to phytoplankton release or nitrification - the so-called "primary nitrite maximum" (Olson, 1981; Dore and Karl, 1996; Lomas and Lipschultz, 2006). "Secondary nitrite maxima" occur deeper down in certain severely oxygen-deficient water columns known as oxygen minimum zones (OMZs). Secondary $\mathrm{NO}_{2}^{-}$maxima were first reported in the Arabian Sea in the 1930s (Gilson, 1937), then later also in the eastern tropical north and south Pacific (Brandhorst, 1959; Wooster et al., 1965). Because of the associated low-oxygen conditions, such $\mathrm{NO}_{2}^{-}$accumulations are conventionally believed to signify active heterotrophic denitrification, and have since led to a number of denitrification studies particularly targeting $\mathrm{NO}_{2}^{-}$-laden waters in the past decades, and the obtained point-measurements have frequently been extrapolated to basin-scale N-loss (Fiadeiro and Strickland, 1968; Cline and Richards, 1972; Codispoti and Packard, 1980; Codispoti and Christensen, 1985; Codispoti et al., 1986; Naqvi, 1987; Lipschultz et al., 1990; Devol et al., 2006; Ward et al., 2009). Currently, oceanic OMZs are considered responsible for $30-50 \%$ of global oceanic N-loss (Gruber and Sarmiento, 1997; Codispoti et al., 2001; Gruber, 2008).

The Arabian Sea is a semi-enclosed basin with the biogeochemical cycling therein and the surface biological production strongly influenced by seasonal monsoons (Wiggert et al., 2005). During the summer southwest monsoon, anticyclonic circulation in the northern half of the basin induces upwelling of nutrient-rich water along the western boundary and to a lesser extent in the central basin, thus enhancing biological production in those regions. Strong convective mixing caused by winter northeastern monsoonal winds deepens the mixed layer especially in the north, bringing in nutrients from the deep and stimulating surface production. In the two intermonsoonal periods, surface water becomes largely oligotrophic within the basin. Large N-deficits relative to that expected from a constant ratio with phosphate or apparent oxygen utilization (Broecker, 1974; Gruber and Sarmiento, 1997), coincide with prominent secondary $\mathrm{NO}_{2}^{-}$ maxima $(\geq 0.2 \mu \mathrm{M})$, as well as oxygen deficiencies $(<5 \mu \mathrm{M}$ $\mathrm{O}_{2}$ ) in the subsurface waters of the central-northeastern Arabian Sea (Naqvi et al., 1990; Bange et al., 2000). These contrast with the lack of prominent $\mathrm{NO}_{2}^{-}$accumulations or oxygen deficiencies in the more productive waters westwards (Naqvi, 1991). Hence, the majority of denitrification or $\mathrm{N}$ loss has been assumed to occur in the central-NE part of the Arabian Sea (Naqvi, 1991).
Consequently, while direct $\mathrm{N}$-loss rate measurements in the Arabian Sea have been few, those that took place have primarily focused on the zone of prominent secondary $\mathrm{NO}_{2}^{-}$ maximum in the central-NE basin (Devol et al., 2006; Nicholls et al., 2007; Ward et al., 2009). Only one recent study compared N-loss in the central-NE Arabian Sea with the more productive waters towards the Omani Shelf. Surprisingly, orders of magnitude higher N-loss rates were detected over the shelf (Jensen et al., 2011), versus the very low to undetectable rates in the presumed "active denitrification zone". While this showed a spatial coupling between $\mathrm{N}$-loss and surface biological production that was in accord with other major OMZs (Kuypers et al., 2005; Thamdrup et al., 2006; Hamersley et al., 2007), the lack of substantial detectable active N-loss in the central-NE Arabian Sea is difficult to reconcile with the prominent secondary $\mathrm{NO}_{2}^{-}$maxima and $\mathrm{N}$-deficits therein.

Here we investigate the $\mathrm{NO}_{2}^{-}$accumulation in the centralNE Arabian Sea OMZ by examining the active production and consumption mechanisms of $\mathrm{NO}_{2}^{-}$, including nitrification, $\mathrm{NO}_{3}^{-}$-reduction, $\mathrm{N}_{2} \mathrm{O}$ production and DNRA that likely co-occur with N-loss in the OMZs (Lam et al., 2009; Lam and Kuypers, 2011); and compare these findings with those obtained near the Omani Shelf. Activities of these processes were determined via a combination of ${ }^{15} \mathrm{~N}$-incubation experiments, flux modeling based on nutrient profiles, and expression analyses of biomarker functional genes for respective processes. Lastly, the suitability of $\mathrm{NO}_{2}^{-}$accumulations as a conventional active $\mathrm{N}$-loss indicator, and its relationship with $\mathrm{N}$-deficits in the OMZs are further discussed.

\section{Methods}

\subsection{Water sampling and nutrient analyses}

Sampling was conducted along a cruise-track encompassing the Omani Shelf and the central-NE Arabian Sea (Fig. 1) at the beginning of the 2007 autumn intermonsoon (Sept/Oct). Samples were collected using a Conductivity-TemperatureDepth (CTD) rosette system equipped with 101 Niskin bottles (Sea-Bird Electronics Inc.) on board the R/V Meteor (M74/1b). Water samples were analysed for $\mathrm{NH}_{4}^{+}, \mathrm{NO}_{2}^{-}$, $\mathrm{NO}_{3}^{-}$and $\mathrm{PO}_{4}^{3-}$ (limits of detection of methods used: 20, 30,100 and $100 \mathrm{nM}$ respectively) at 10 to $25 \mathrm{~m}$ intervals for 12 stations along roughly the cruise-track of the former US Joint Global Ocean Flux Study (Morrison et al., 1999) (Fig. 1). $\mathrm{NH}_{4}^{+}$and $\mathrm{NO}_{2}^{-}$concentrations were analyzed immediately after sampling with fluorometric and spectrophotometric techniques, respectively (Grasshoff, 1983; Holmes et al., 1999). Samples for $\mathrm{NO}_{3}^{-}$and $\mathrm{PO}_{4}^{3-}$ were stored frozen and measured spectrophotometrically (Grasshoff et al., 1999) with an autoanalyzer (TRAACS 800, Bran and Luebbe, Germany) in a shore-based laboratory. $\mathrm{N}_{2} \mathrm{O}$ in seawater sub-sampled from Niskin bottles was analyzed on 


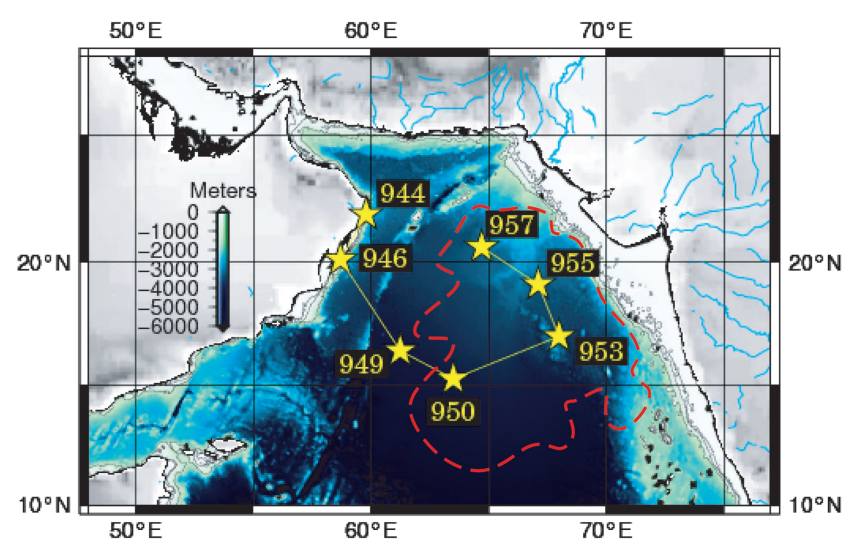

Fig. 1. Sampling stations (stars and station numbers) along cruise track (yellow) in the Arabian Sea in Sept/Oct 2007. The red dashed line marks the prominent secondary $\mathrm{NO}_{2}^{-}$maximum of $\geq 1 \mu \mathrm{M}$ in the central-northeastern basin (Naqvi, 1991).

shipboard by introducing equilibrated headspace samples through a moisture trap and a gas chromatograph at $190^{\circ} \mathrm{C}$ with a packed molecular sieve column $(1.83 \mathrm{~m} \times 3.175 \mathrm{~mm}$ (1/8") SS, 5A, mesh 80/100, Alltech GmbH, Germany), and $\mathrm{N}_{2} \mathrm{O}$ was subsequently detected with an electron capture detector as previously described (Walter et al., 2006). Ndeficits were estimated from the measured total inorganic nitrogen (i.e. $\mathrm{NH}_{4}^{+}+\mathrm{NO}_{2}^{-}+\mathrm{NO}_{3}^{-}$) and $\mathrm{PO}_{4}^{3-}$ concentrations as $\mathrm{N}^{*}$ (in units of $\left.\mu \mathrm{M}\right)=\left[\mathrm{NH}_{4}^{+}+\mathrm{NO}_{2}^{-}+\mathrm{NO}_{3}^{-}\right]-16$ $\left[\mathrm{PO}_{4}^{3-}\right]+2.9 \mu \mathrm{mol} \mathrm{kg}^{-1} \times$ density (Gruber and Sarmiento, 1997). These N-deficit estimates may be conservative, however, if there is preferential degradation of organic nitrogen as found previously in oxygen-deficient waters (Van Mooy et al., 2002), or remineralization of $\mathrm{N}$-rich organic matter such as potentially resulted from spatially coupled $\mathrm{N}_{2}$-fixation (Capone et al., 1998; Deutsch et al., 2007). Neutral densities were computed from CTD data according to Jackett and McDougall (1997). They are used as reference frames to view nutrient distributions, because water masses preferentially move and mix along neutral density surfaces, or isoneutrals, which are commonly approximated by surfaces of (potential) density, or isopycnals. Nonetheless, isopycnals have to be calculated from some arbitrarily chosen reference pressures and thermobaricity introduces an error when water parcels deviate from the reference pressures. In the Indian Ocean, such discrepancies between the vertical locations of isopycnals and isoneutrals could be substantial (You and McDougall, 1990), and so isoneutrals were used in the current study instead.

\section{$2.2 \quad{ }^{15} \mathrm{~N}$-Stable isotope pairing experiments}

${ }^{15} \mathrm{~N}$-stable isotope pairing experiments were conducted at six depths throughout the OMZ at each of seven sampling stations (Fig. 1), including two stations near the Omani Shelf and five in the central-NE basin characterized by a prominent secondary nitrite maximum $\left(\mathrm{NO}_{2}^{-} \geq 0.2 \mu \mathrm{M}\right)$. Rate determinations for anammox, denitrification and DNRA from these experiments have been reported in Jensen et al. (2011). As these three processes are potential $\mathrm{NO}_{2}^{-}$sinks, some of the main findings are described in the current paper for the evaluation of overall $\mathrm{NO}_{2}^{-}$balance. Using the same set of isotope-pairing experiments, ${ }^{15} \mathrm{NO}_{2}^{-}$production was additionally measured in incubations with ${ }^{15} \mathrm{NH}_{4}^{+}+{ }^{14} \mathrm{NO}_{2}^{-}$ $\left(5 \mu \mathrm{M}\right.$ each) and with ${ }^{15} \mathrm{NO}_{3}^{-}(20 \mu \mathrm{M})$, in order to determine ammonia oxidation and nitrate reduction rates, respectively (McIlvin and Altabet, 2005; Lam et al., 2009). All incubations were conducted at non-detectable $\mathrm{O}_{2}$ levels after purging with helium for $15 \mathrm{~min}(\leq 0.5 \mu \mathrm{M})$ (Dalsgaard et al., 2003; Jensen et al., 2008, 2011), except for the oxygenregulation experiments. In the latter, various amounts of $\mathrm{O}_{2}-$ saturated water were injected into the incubation vials which had previously been purged with helium, and the 4 different $\mathrm{O}_{2}$ levels achieved within the range of $0-12 \mu \mathrm{M}$ (Table B1) were verified with an oxygen microsensor. All experiments were time-series incubations of approximately $0,6,12,24$, and $48 \mathrm{~h}$ conducted at in situ temperature and in the dark. Rates were calculated from the slopes of linear regressions of ${ }^{15} \mathrm{~N}$-production as a function of time (limits of detection of methods for $\mathrm{N}_{2}, \mathrm{NO}_{2}^{-}$and $\mathrm{NH}_{4}^{+}$production: $0.15-0.20$, 0.5 and $0.5 \mathrm{nM} \mathrm{d}^{-1}$, respectively), and only those with significant production without an initial lag-phase were considered (slope significantly different from zero, $t$-tests with $p<0.05$ ). Presented are net production rates that have been corrected for the mole fractions of ${ }^{15} \mathrm{~N}$ in initial substrate pools. Any isotope dilution in the substrate pools due to the co-occurrence of other concurrent $\mathrm{N}$-cycling processes in the course of incubation, have not been corrected for in these rate calculations.

\subsection{Functional gene detection and expression analyses}

Water samples (10-151) for nucleic acid analyses were filtered through $0.22 \mu \mathrm{m}$ Sterivex filters (Millipore) and stored at $-80^{\circ} \mathrm{C}$ until extraction in a shore-based laboratory. RNA and DNA were extracted from the same filters using the Totally RNA Kit (Ambion) with a prior cell lysis $\left(10 \mathrm{mg} \mathrm{ml}^{-1}\right.$ lysozyme in $10 \mathrm{mM}$ Tris-EDTA, pH 8; 4 units of SUPERaseIn, Ambion) performed within filter cartridges. Various biomarker functional genes for ammonia oxidation (both archaeal and bacterial), nitrate reduction, anammox, denitrification and DNRA (Table B2) were analyzed using both qualitative and quantitative polymerase chain reactions (PCR). Active expression of these functional genes as transcripts (mRNA), were additionally analyzed via reverse transcription (RT) (Superscript III First-Strand Synthesis Master Mix, Invitrogen) with the respective gene-specific antisense primers, followed by quantification with real-time PCR (Lam et al., 2009; Jensen et al., 2011). The expressed nitric oxide reductase genes (nor $B$ ), which encode the enzyme 
responsible for the reduction of nitric oxide to $\mathrm{N}_{2} \mathrm{O}$, were RT-PCR amplified and cloned with the TOPO TA Cloning Kit for sequencing (Invitrogen). Positive inserts were sequenced with ABI370XL sequencers (Applied Biosystems) by the GATC Biotech sequencing services, and phylogenetic analyses based on amino acids translated from nor $B$ genes were performed with the ARB package (Ludwig et al., 2004). New real-time PCR primers and probes for specific groups of norB were designed using the Oligo Design and Analysis Tools (Integrated DNA Technologies), and were further verified with BLAST (Altschul et al., 1997) and own ARB database compiled from norB sequences currently available in public databases. All primers and PCR protocols used in this study were listed in Table B2.

Expressions (transcriptions) of key functional genes initiate the production of enzymes that mediate the processes of interest, as opposed to gene presence that merely indicate the genetic potentials of organisms which may never utilize these genes and perform these reactions in situ. Active gene expression in unmanipulated seawater samples can thus serve as independent support for an active process detected, though the relationships between rates and gene expressions are not necessarily straightforward due partly to the vastly different detection limits of various measurement types, and partly to the influence from other transcriptional factors such as stresses, physiological states and post-transcriptional processes. Because a lot is yet to be explored of the immense oceanic microbiome, we do not claim an exhaustive coverage of the functional gene targets by the selected primers.

\subsection{Reaction-diffusion modeling and statistical analyses}

Net production and consumption rates $(R)$ of $\mathrm{NH}_{4}^{+}, \mathrm{NO}_{2}^{-}$, $\mathrm{NO}_{3}^{-}, \mathrm{N}_{2} \mathrm{O}$ and $\mathrm{N}^{*}$ in the water column of the centralNE Arabian Sea were estimated from their respective measured concentration $(\mathrm{C})$ profiles based on a reaction-diffusion model, which is similar to those often applied in sediment porewater studies (Berg et al., 1998):

$\frac{d}{d z}\left(K(z) \frac{d C}{d z}\right)+R=0$

where $K_{(z)}$ is vertical eddy diffusivity and $\mathrm{z}$ is depth. $K_{(z)}$ is parameterized from Brunt-Väisälä frequencies (Gargett, 1984; Gregg et al., 1986; Fennel and Boss, 2003) computed from CTD data. These input data were interpolated to a computational grid and the differential Eq. (1) was transformed into an inverse linear system. Subsequently, $R$ at the various interpolated depth intervals $(z)$ was solved via a numerical method known as Tikhonov regularization. The detailed procedures are described in Lettmann et al. (2011). This model assumes steady states and a lack of significant horizontal advection over the time-spans under consideration, and is thus applied for the central-NE Arabian Sea and not for the western Arabian Sea, due to obvious upwelling and horizontal intrusion of Persian Gulf Water in the latter region. All computations for reaction-diffusion models, as well as statistical analyses (Statistics Toolbox), were performed with MATLAB (Mathworks, Inc.).

\section{Results and discussion}

\subsection{Distributions of dissolved inorganic nitrogen and oxygen}

Consistent with past observations, nutrient profiling revealed a prominent secondary $\mathrm{NO}_{2}^{-}$maximum reaching $\sim 5 \mu \mathrm{M}$ in the central-NE basin (Stations 950-958), centered along the $26.0-26.5 \mathrm{~kg} \mathrm{~m}^{-3}$ neutral-density surfaces, or isoneutrals (Fig. 2b). These coincided with local $\mathrm{NO}_{3}^{-}$minimum and severe $\mathrm{N}$-deficits represented by the most negative $\mathrm{N}^{*}$ values (Gruber and Sarmiento, 1997), where oxygen concentrations fell below $10 \mu \mathrm{M}$ or apparently anoxic $(<90 \mathrm{nM})$ as determined by a highly sensitive STOX (Switchable Trace amount OXygen) sensor (Revsbech et al., 2009; Jensen et al., 2011) (Fig. 2 a, e, g). $\mathrm{N}_{2} \mathrm{O}$ also accumulated in these oxygendeficient waters, and was elevated towards the central-NE basin reaching as high as $91 \mathrm{nM}$ (Fig. 2d). Shoaling of isoneutrals (Fig. 2h) and higher surface chlorophyll- $a$ concentrations (Jensen et al., 2011) were observed near the Omani Shelf, indicating residual upwelling and enhanced biological production westward. Surface particulate organic carbon and nitrogen were consequently elevated over the shelf (Jensen et al., 2011), and so were the concentrations of the remineralized $\mathrm{NH}_{4}^{+}(\leq 1.6 \mu \mathrm{M})($ Fig. $2 \mathrm{c})$. $\mathrm{NH}_{4}^{+}$concentrations decreased with depth and were largely close to detection limit $(\sim 20 \mathrm{nM})$ towards the central-NE basin.

\subsection{Sources of nitrite}

\subsubsection{Nitrate reduction to nitrite}

Nitrate reduction to nitrite $\left(\mathrm{NO}_{3}^{-}+2 \mathrm{H}^{+}+2 \mathrm{e}^{-} \rightarrow \mathrm{NO}_{2}^{-}+\mathrm{H}_{2} \mathrm{O}\right)$ is the first step in both denitrification and DNRA, but it is also a standalone process that provides the majority of $\mathrm{NO}_{2}^{-}$ for anammox in the eastern tropical south Pacific (ETSP) OMZ (Lam et al., 2009). In the central-NE Arabian Sea, $\mathrm{NO}_{2}^{-}$was previously observed to accumulate in the upper $\mathrm{OMZ}$ at rates equivalent to the means of $56 \%$ and $14 \%$ of net $\mathrm{NO}_{3}^{-}$loss near stations 950 and 957, respectively, thus indicating the occurrence $\mathrm{NO}_{3}^{-}$-reduction to $\mathrm{NO}_{2}^{-}$(Nicholls et al., 2007). In congruence, direct rate measurements of ${ }^{15} \mathrm{NO}_{3}^{-}$reduction to ${ }^{15} \mathrm{NO}_{2}^{-}$in the current study showed readily detectable $\mathrm{NO}_{3}^{-}$-reduction activity within the central-NE OMZ (up to $29.7 \pm 4.8 \mathrm{nMd}^{-1}$ ) (Fig. 3d), and with rates comparable to those recorded towards the Omani Shelf (up to $\left.24.9 \pm 1.8 \mathrm{nM} \mathrm{d}^{-1}\right)\left(\right.$ Fig. A1). The offshore $\mathrm{NO}_{3}^{-}$-reduction rates fell within the range of those measured in the ETSP OMZ (Lipschultz et al., 1990; Lam et al., 2009), and reached a local maximum at $200 \mathrm{~m}$ at St. 957, coinciding with a local 

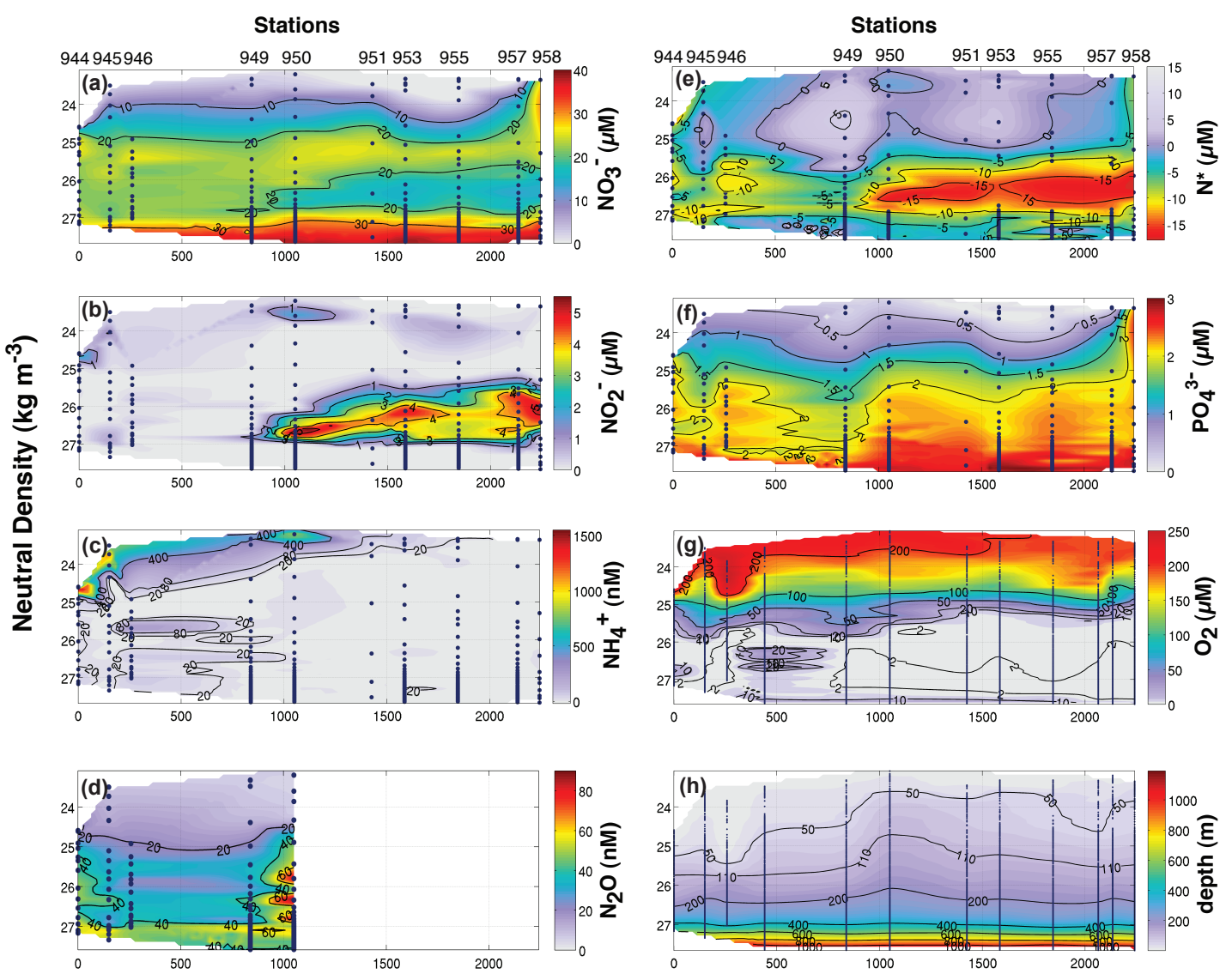

Fig. 2. Distribution of dissolved inorganic nitrogen, phosphate and oxygen throughout the oxygen minimum zone along the cruise track from the Omani Shelf leading to the central-northeastern Arabian Sea, plotted against neutral density: (a) nitrate, (b) nitrite, (c) ammonium, (d) nitrous oxide, (e) nitrogen deficits as $\mathrm{N}^{*}$ (in $\mu \mathrm{M}=[$ Total inorganic nitrogen $]-16\left[\mathrm{PO}_{4}^{3-}\right]+2.9 \mu \mathrm{mol} \mathrm{kg}^{-1} \times$ density), (f) phosphate, (g) dissolved oxygen and (h) the corresponding depths along the neutral density surfaces.

minimum in $\mathrm{NO}_{3}^{-}$(Figs. 2 and 3). Although these rates were less than half of those estimated by concentration differences in Nicholls et al. (2007), consistent vertical rate distributions could be observed between the two studies at this station. In addition, the vertical distribution of $\mathrm{NO}_{3}^{-}$-reduction rates strongly resembled that of $\mathrm{NO}_{2}^{-}$concentrations $(r=0.94$, $p<0.005$, Pearson correlation), implying a strong influence of the former on the secondary $\mathrm{NO}_{2}^{-}$maxima.

The occurrence of $\mathrm{NO}_{3}^{-}$reduction was further corroborated by the active expression of the biomarker membranebound nitrate reductase gene, narG. The transcript (mRNA) levels determined by RT-qPCR were consistently detectable throughout the OMZ at all stations (Fig. 3, A1-2). Active transcription of another $\mathrm{NO}_{3}^{-}$reducing functional gene, $n a p A$, encoding the periplasmic nitrate reductase, was however not analyzed in this study. It could also have contributed to $\mathrm{NO}_{3}^{-}$reduction in the $\mathrm{OMZ}$ but perhaps to a smaller extent (Lam et al., 2009), and thus could partly explain the lack of clear correlation between rates and narG gene expression levels.

\subsubsection{Ammonia oxidation}

Ammonia oxidation to $\mathrm{NO}_{2}^{-}$, the first step of nitrification, has been demonstrated to be a significant $\mathrm{NO}_{2}^{-}$source in the ETSP OMZ (Lam et al., 2009). However, ammonia oxidation was only measurable in the upper part of the central-NE Arabian Sea OMZ (up to $3.6 \pm 0.04 \mathrm{nM} \mathrm{d}^{-1}$ ), and only when oxygen concentrations were $\geq 8 \mu \mathrm{M}$ based on incubation experiments at various controlled oxygen levels (Table B2). This contrasts with results from the Omani Shelf, where high ammonia oxidation rates (up to $12.5 \pm 3.5 \mathrm{nMd}^{-1}$ ) could be detected even in helium-purged incubations for depths deeper into the OMZ (down to $150 \mathrm{~m}$ ) where oxygen was undetectable ( $\leq 0.5 \mu \mathrm{M})$ (Fig. 3). Ammonia oxidation in general seemed to be heavily driven by ammonia-oxidizing archaea, as ammonia oxidation rates were significantly correlated with crenarchaeal cellular abundance determined by 16S rRNA-targeted CARD-FISH (Spearman $\mathrm{R}=0.705, p<$ 0.05) (data not shown), as well as with the transcript-to-gene ratio of archaeal amoA (Spearman $\mathrm{R}=0.564, p<0.0005)$ 


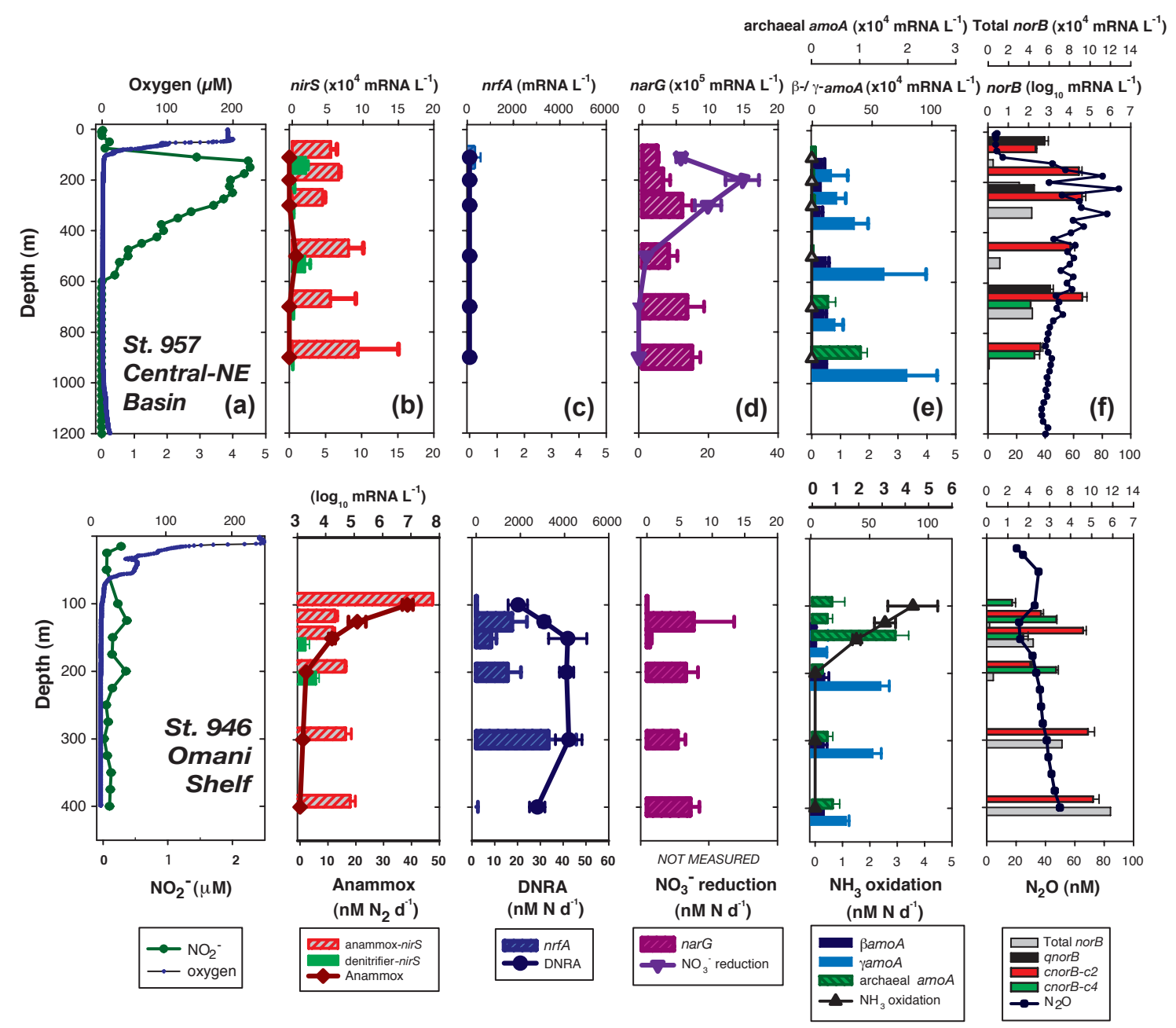

Fig. 3. Typical vertical distributions of various chemical and N-cycling functional gene expressions observed in the central-northeastern Arabian Sea OMZ (St. 957, upper panels) and the Omani Shelf OMZ (St. 946, lower panels): (a) oxygen and $\mathrm{NO}_{2}^{-}$, (b) anammox rates and the expression of anammox- and denitrifier- $n i r S$ genes, (c) DNRA rates and $n r f A$ expression, (d) nitrate reduction rates and narG expression, (e) ammonia oxidation rates, crenarchaeal and bacterial amoA expressions, (f) $\mathrm{N}_{2} \mathrm{O}$ and the expression of various forms of quinol- and cytochrome-containing norB genes. The $\mathrm{N}_{2} \mathrm{O}$ profile for central-NE basin was obtained from St. 950. Please note the different scales used to accommodate the much higher values obtained over the shelf as highlighted in bold. Error bars for rates are standard errors calculated from linear regression, and those for gene expressions represent standard deviations from triplicate real-time PCR runs. Although denitrification rate measurements were made, there was no convincing evidence of its active occurrence.

(Figs. A3 and A4). The amoA gene encodes ammonia monooxygenase subunit A, a key enzyme mediating ammonia oxidation. Ammonia oxidation might also be partly attributed to $\beta$ - and $\gamma$-proteobacterial ammonia-oxidizers, as their amoA's were readily expressed throughout the OMZ at levels $\geq 4$-fold greater than those of their archaeal counterparts. Unlike the Peruvian OMZ where archaeal amoA generally predominated at the gene level (Lam et al., 2009), combined bacterial amoA gene abundance was comparable to archaeal amoA in the OMZ especially at the central-NE stations (St. 953, 955, 957) (Fig. A3 d, e, f). As oxygen was depleted $(<90 \mathrm{nM})$ within the central-NE OMZ core where ammonia oxidation rates were not measurable, ammonia- oxidizers could be undertaking alternative anaerobic pathways (Poth and Focht, 1985), such as reducing $\mathrm{NO}_{2}^{-}$to $\mathrm{N}_{2} \mathrm{O}$ in the so-called nitrifier-denitrification. Overall, ammonia oxidation represented only a minor $\mathrm{NO}_{2}^{-}$source $(\sim 4-11 \%$ of total depth-integrated $\mathrm{NO}_{2}^{-}$production) relative to $\mathrm{NO}_{3}^{-}$reduction in the Arabian Sea OMZs, with the lower values obtained from the central-NE basin (Table 1). 
Table 1. (A) Estimated depth-integrated rates of $\mathrm{NO}_{2}^{-}$sources and sinks in the Arabian Sea OMZ $\left(\mathrm{O}_{2}<10 \mu \mathrm{M}\right)$ over the Omani Shelf vs. the central-northeastern basin, based on rates measured via ${ }^{15} \mathrm{~N}$-incubation experiments. (B) Modeled fluxes of $\mathrm{NH}_{4}^{+}, \mathrm{NO}_{2}^{-}, \mathrm{NO}_{3}^{-}, \mathrm{N}_{2} \mathrm{O}$ and net $\mathrm{N}$-loss in the central-northeastern Arabian Sea OMZ. All rates are expressed in units of $\mathrm{mmol} \mathrm{N} \mathrm{m}^{-2} \mathrm{~d}^{-1}$. The net $\mathrm{NO}_{2}^{-}$balance in the central-NE OMZ estimated from the measured and modeled fluxes are highlighted in italic for comparison. The respective integrated N-loss estimates are indicated in bold.

\begin{tabular}{|c|c|c|c|c|c|}
\hline \multicolumn{3}{|c|}{ (A) Measured fluxes } & \multicolumn{3}{|c|}{$\begin{array}{l}\text { (B) Modeled net fluxes } \\
\text { Central-NE Basin }\end{array}$} \\
\hline & St. 946 & St. 957 & & St. 957 & $\begin{array}{c}\text { Mean }( \pm \mathrm{SD}) \\
\text { of } 4 \text { stations }\end{array}$ \\
\hline $\begin{array}{l}\mathrm{NO}_{2}^{-} \text {sources } \\
\mathrm{NO}_{3}^{-} \text {reduction } \\
\mathrm{NH}_{3} \text { oxidation }\end{array}$ & $\begin{aligned}> & 4.81^{\mathrm{a}} \\
& 0.17\end{aligned}$ & $\begin{array}{c}6.91 \\
0.24^{\mathrm{b}}\end{array}$ & $\begin{array}{l}\text { Depth } \\
\mathrm{O}_{2}\end{array}$ & $\begin{array}{l}100-1000 \mathrm{~m} \\
<10 \mu \mathrm{M}\end{array}$ & $\begin{array}{c}\sim 100-1000 \mathrm{~m}^{*} \\
\quad<10 \mu \mathrm{M}\end{array}$ \\
\hline Total & $>4.98$ & 7.15 & $\mathrm{NO}_{3}^{-}$ & 0.08 & $0.19 \pm 0.16$ \\
\hline $\mathrm{NO}_{2}^{-}$sinks & & & $\mathrm{NO}_{2}^{-}$ & 0.09 & $0.05 \pm 0.03$ \\
\hline Anammox & 2.45 & $0.06^{\mathrm{c}}$ & $\mathrm{N}_{2} \mathrm{O}^{\mathrm{e}}$ & & 0.00042 \\
\hline $\mathrm{NO}_{2}^{-}$oxidation ${ }^{\mathrm{d}}$ & $\geq 0.17$ & 7.03 & $\mathrm{NH}_{4}^{+}$ & -0.00014 & $-0.0002 \pm 0.0002$ \\
\hline DNRA & 12.04 & 0 & & & \\
\hline Total & $\geq 14.66$ & 7.09 & & & \\
\hline $\mathrm{NO}_{2}^{-}$Balance & $\geq-9.68^{* *}$ & 0.06 & & & \\
\hline Total N-loss & 4.91 & $0.12^{c}$ & N-loss f & 0.15 & $0.11 \pm 0.05$ \\
\hline
\end{tabular}

a No data from St. 946; data taken from St. 944, but due to oxygen intrusion in mid-water that might have lowered $\mathrm{NO}_{3}^{-}$reduction, higher rates for St. 946 is expected. In addition, because anammox and DNRA rates were relatively high at this station, the gross $\mathrm{NO}_{3}^{-}$reduction rates should be higher than the net rates listed - unlike the lack of significant anammox and DNRA in the central-NE OMZ.

${ }^{\text {b }}$ Data from St. 953 where in situ $\mathrm{O}_{2}$ concentrations were used in experiments for the upper OMZ, since only anoxic incubations were conducted at St. 957.

${ }^{c}$ Potential rates only from experiments with ${ }^{15} \mathrm{NO}_{2}^{-}+{ }^{14} \mathrm{NH}_{4}^{+}$.

${ }^{\mathrm{d}}$ Rates estimated as the sum of modeled net change in $\mathrm{NO}_{3}^{-}$(not $\mathrm{NO}_{2}^{-}$) and the measured $\mathrm{NO}_{3}^{-}$reduction rates for St. 957. Due to horizontal advection over the Omani Shelf, $\mathrm{NO}_{3}^{-}$ fluxes cannot be estimated with the current models for St. 946. Instead, as $\mathrm{NH}_{3}$ oxidation (first step of nitrification) was detected, we estimate $\mathrm{NO}_{2}^{-}$oxidation rates to be at least equal to $\mathrm{NH}_{3}$ oxidation rates.

e From St. 950.

${ }^{\mathrm{f}}$ Modeled net N-loss rates were calculated as the net production of more negative $\mathrm{N}^{*}$.

* Except for St. 950 where the OMZ started at $155 \mathrm{~m}$.

** Because of the current regimes over/near shelf regions, advective inputs and outputs are likely significant that the calculated balance should not be taken too literally. Besides, as only net $\mathrm{NO}_{3}^{-}$reduction rates are listed here, the large amounts of $\mathrm{NO}_{2}^{-}$consumed via anammox and DNRA would imply significantly higher gross $\mathrm{NO}_{3}^{-}$reduction, whereas the insignificant anammox and DNRA rates in the central-NE render the net rates reasonable estimates therein.

\subsection{Sinks of nitrite}

\subsubsection{Nitrite reduction via anammox, denitrification and DNRA}

At the time of our sampling, high rates of $\mathrm{N}_{2}$ production from $\mathrm{NO}_{2}^{-}$(up to $38.6 \mathrm{nMN}_{2} \mathrm{~d}^{-1}$ ), due mostly to anammox as well as in coupling with DNRA, were measured in waters near the Omani Shelf (Jensen et al., 2011), a region previously considered inconducive to active $\mathrm{N}$-loss due to the presence of oxygen (Fig. 3). Oxygen-deficient conditions ( $\leq \sim 2 \mu \mathrm{M})$ were in fact observed below $\sim 110 \mathrm{~m}$ depth over the shelf, along with very negative $\mathrm{N}^{*}$ (down to $<-10 \mu \mathrm{M}$ ) but low $\mathrm{NO}_{2}^{-}(<0.5 \mu \mathrm{M})$ at $\mathrm{OMZ}$ depths (Fig. 2). In contrast, only low and sporadic rates of $\mathrm{N}_{2}$ production from $\mathrm{NO}_{2}^{-}(0-$ $1.8 \mathrm{nM} \mathrm{N}_{2} \mathrm{~d}^{-1}$ ) were detected in the central-NE Arabian Sea
OMZ (Figs. 3 and A2), which is generally considered the "active denitrification zone" where the prominent secondary $\mathrm{NO}_{2}^{-}$maximum lay (Naqvi, 1991; Bange et al., 2000). When detected, $\mathrm{N}_{2}$ production was either due to anammox, or the exact pathway could not be fully resolved from the ${ }^{15} \mathrm{~N}$ isotope pairing experiments (Jensen et al., 2011). There was no clear unambiguous evidence for active denitrification or DNRA in the central-NE Arabian Sea OMZ (Figs. 3 and A2).

Nevertheless, denitrifier-type $c d_{1}$-containing nitrite reductase gene (nirS) was abundant in the central-NE OMZ and showed relatively consistent expression at two stations (St. 953, 955) (Fig. A2b and d). These results suggested that denitrifiers were potentially active in the central-NE Arabian Sea, but not active enough to confer measurable rates in our study (no significant ${ }^{30} \mathrm{~N}_{2}$ production from ${ }^{15} \mathrm{NO}_{2}^{-}$ without time-lag) (Jensen et al., 2011). Although another 
recent study reported some moderate denitrification rates at three stations in this region (Ward et al., 2009), detailed timecourse data revealed considerable initial time-lags in the incubations for at least the representative depth shown (Bulow et al., 2010). Should the same criteria be used for rate calculations (e.g. elimination of data with initial time-lags or exponential increase after long incubation hours), results from the two studies might not be so disparate (Jensen et al., 2011). Meanwhile, active denitrification during other times cannot be ruled out, due to the apparently high spatiotemporal variabilities in the Arabian Sea.

\subsection{2 $\mathrm{N}_{2} \mathrm{O}$ production}

Alternatively, some $\mathrm{NO}_{2}^{-}$might be reduced to $\mathrm{N}_{2} \mathrm{O}$ instead of $\mathrm{N}_{2}$. This was suggested by the active expression of a diverse group of nor $B$ genes, which encode nitric oxide (NO) reductases for the conversion of $\mathrm{NO}$ to $\mathrm{N}_{2} \mathrm{O}$ (Fig. A5). Transcripts of both quinol- and cytochrome-bc-types of norB (qnorB and $\operatorname{cnor} B$, respectively) related to various denitrifying bacteria could be detected in the central-NE Arabian Sea OMZ (Fig. A5). The latter form, cnorB, was more abundant and was present also at near-shelf stations (Figs. 3 and A1-2). It consisted of at least 3 sub-clusters (Fig. A5). The dominant sub-cluster ASc2 was expressed throughout the OMZ, while ASc4 transcripts only occurred at local $\mathrm{N}_{2} \mathrm{O}$ minima or OMZ boundaries (Figs. 3 and A1-2).

Despite the lack of detectable production of ${ }^{15} \mathrm{~N}$-labeled$\mathrm{N}_{2} \mathrm{O}$ from ${ }^{15} \mathrm{NO}_{2}^{-}$-incubations in the central-NE OMZ (data not shown), a reaction-diffusion model based on an $\mathrm{N}_{2} \mathrm{O}$ concentration profile (St. 950) indicated a net $\mathrm{N}_{2} \mathrm{O}$ production of $\leq 6 \mathrm{pMd}^{-1}$ in the upper part of the OMZ (Fig. 4). This crude rate estimate was indeed below our detection limit $\left(\sim 500 \mathrm{pM} \mathrm{d}^{-1}\right)$, but the depth horizon of modeled $\mathrm{N}_{2} \mathrm{O}$ production ( $\sim 200-300 \mathrm{~m})$ was consistent with the total norB expression observed at the central-NE Station 957 (Figs. 3f and 4f). These findings are also in good agreement with the previous detection of ${ }^{15} \mathrm{~N}$-labeled $\mathrm{N}_{2} \mathrm{O}$ produced from ${ }^{15} \mathrm{NO}_{x}^{-}$ via single-end-point incubations $(\sim 96 \mathrm{~h})$ for the upper OMZ depths in the same region (Nicholls et al., 2007).

However, $\mathrm{N}_{2} \mathrm{O}$ may also be produced by ammoniaoxidizers either via $\mathrm{NO}_{2}^{-}$or hydroxylamine (Ritchie and Nicholas, 1972), based on active amoA expression yet lack of detectable ${ }^{15} \mathrm{NO}_{2}^{-}$-production from ${ }^{15} \mathrm{NH}_{4}^{+}$-incubations within the $\mathrm{OMZ}$ core. Potential production of ${ }^{15} \mathrm{~N}$-labeled$\mathrm{N}_{2} \mathrm{O}$ from ${ }^{15} \mathrm{NH}_{4}^{+}$-incubations was indeed reported for the upper OMZ depths, despite this being an apparently minor $(\sim 2-5 \%)$ contribution of $\mathrm{N}_{2} \mathrm{O}$ relative to the reductive pathway (Nicholls et al., 2007). Although no immediate relatives of known ammonia-oxidizer $\operatorname{cnor} B$ sequences were recovered in our cnorB clone libraries, it cannot be excluded that all four primer sets used (Table B2) were insufficient to capture the full diversity in the environment such as any unknown norB of potentially archaeal origin, or that the $\operatorname{cnor} B$ phylogenies are not equivalent to cell identities based on $16 \mathrm{~S}$
rRNA genes. Regardless of which microbial players were involved, there was a strong indication of an active albeit likely minor $\mathrm{NO}_{2}^{-}$sink via $\mathrm{N}_{2} \mathrm{O}$ production in the upper $\mathrm{OMZ}$ of the central-NE Arabian Sea.

\subsubsection{Nitrite oxidation}

In spite of the oxygen deficiency within the $\mathrm{OMZ}, \mathrm{NO}_{2}^{-}$may also be consumed by $\mathrm{NO}_{2}^{-}$oxidation, the second step of nitrification. In this reaction, $\mathrm{NO}_{2}^{-}$is oxidized to $\mathrm{NO}_{3}^{-}$by $\mathrm{H}_{2} \mathrm{O}$ $\left(\mathrm{NO}_{2}^{-}+\mathrm{H}_{2} \mathrm{O} \rightarrow \mathrm{NO}_{3}^{-}+2 \mathrm{H}^{+}+2 \mathrm{e}^{-}\right)$and the generated electrons are transferred to a terminal electron acceptor, most commonly being $\mathrm{O}_{2}\left(2 \mathrm{H}^{+}+2 \mathrm{e}^{-}+0.5 \mathrm{O}_{2} \rightarrow \mathrm{H}_{2} \mathrm{O}\right.$ ) (Kumar et al., 1983; Hollocher, 1984). Anaerobic growths have been documented for a cultured nitrite-oxidizer (Bock et al., 1988; Griffin et al., 2007), though the exact anaerobic metabolic pathways or whether $\mathrm{NO}_{2}^{-}$is oxidized in such cases remain to be elucidated in environmental settings. In the eastern tropical south Pacific (ETSP), $\mathrm{NO}_{2}^{-}$-oxidizing activities were detected deep into the OMZ and were found rather insensitive to oxygen deficiency (Lipschultz et al., 1990). Although nitrite oxidation rates were not directly measured in our study, reaction-diffusion modeling on concentration profiles clearly indicated net $\mathrm{NO}_{3}^{-}$production coinciding with $\mathrm{NO}_{2}^{-}$consumption, especially in the upper part of the $\mathrm{OMZ}$ (Figs. 4 and A6). To date, there have been no known biotic or abiotic processes other than nitrite oxidation that can produce $\mathrm{NO}_{3}^{-}$in such seawater conditions, except for anammox. In the latter, $0.3 \mathrm{~mol}$ of $\mathrm{NO}_{2}^{-}$is oxidized to $\mathrm{NO}_{3}^{-}$for every mole of $\mathrm{N}_{2}$ produced, as a means to replenish electrons for the acetyl-CoA carbon fixation process within anammox bacteria (van de Graaf et al., 1997; Strous et al., 2006). However, as anammox rates were hardly detectable in the central-NE Arabian Sea, contribution from anammox could not account for the calculated $\mathrm{NO}_{3}^{-}$production.

Assuming $\mathrm{NO}_{2}^{-}$oxidation and $\mathrm{NO}_{3}^{-}$reduction were the only $\mathrm{NO}_{3}^{-}$producing and consuming processes, respectively, $\mathrm{NO}_{2}^{-}$oxidation rates could then be estimated as the sum of the measured $\mathrm{NO}_{3}^{-}$reduction and the modeled net change in $\mathrm{NO}_{3}^{-}$. $\mathrm{NO}_{2}^{-}$oxidation was thus postulated to occur down to

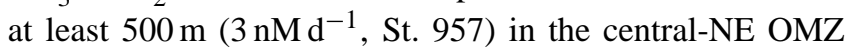
reaching a maximum of $22 \mathrm{nMd}^{-1}$ at $200 \mathrm{~m}$, which was within the range of those reported for the ETSP (Lipschultz et al., 1990). Although these are only crude estimates, the maximum rate coincided with the maximum $\mathrm{NO}_{3}^{-}$reduction rate in the upper part of the OMZ at this station (St. 957), and the two rates were often comparable in magnitude. Hence, $\mathrm{NO}_{2}^{-}$oxidation was most likely the dominant $\mathrm{NO}_{2}^{-}$sink in the central-NE Arabian Sea, but requires further verification with direct rate measurements, and the use of $\mathrm{O}_{2}$ or alternative terminal electron acceptors like iodate, manganese (III or IV) or iron (Farrenkopf et al., 1997; Lewis and Luther, 2000; Trouwborst et al., 2006; Moffet et al., 2007) also remain to be determined. 


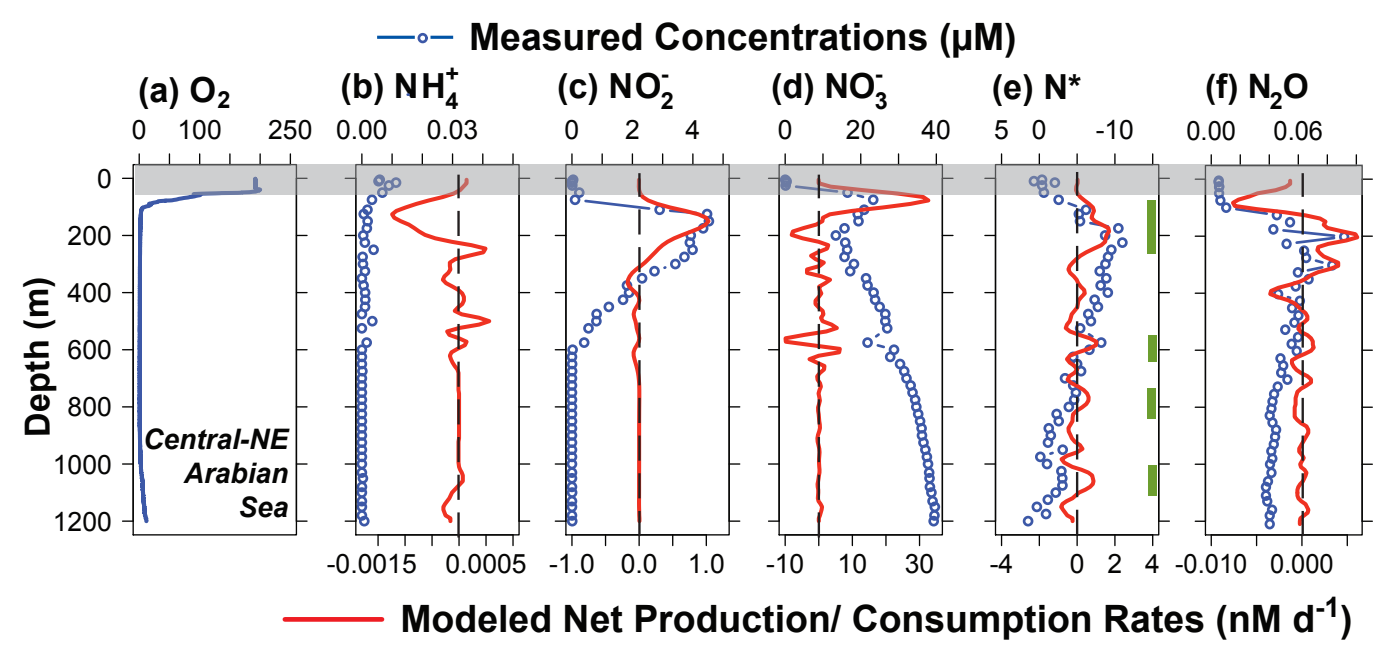

Fig. 4. (a) Vertical distribution of oxygen in the central-NE Arabian Sea (St. 957), along with the corresponding profiles of measured concentrations of inorganic nitrogen, based on which net production (positive) or consumption (negative) rates were modeled: $(\mathbf{b}) \mathrm{NH}_{4}^{+}$, (c) $\mathrm{NO}_{2}^{-}$, (d) $\mathrm{NO}_{3}^{-}$and (e) $\mathrm{N}^{*}$. In case of (e) $\mathrm{N}^{*}$, positive rates reflect production of more severe $\mathrm{N}$-deficits (i.e. more negative $\mathrm{N}^{*}$ ). Also shown in (f) are the profiles of $\mathrm{N}_{2} \mathrm{O}$ concentrations and modeled consumption/ production from St. 950. Green bars indicate depths at which modeled rates fell within detectable ranges via isotope pairing techniques. The shaded area marks the surface mixed layer, for which the modeled rates should be treated with caution.

\subsection{Nitrite accumulations, $\mathrm{N}$-loss and organic matter in the central-NE OMZ}

Taken together, we found ample evidence for $\mathrm{NO}_{2}^{-}$production within the prominent secondary $\mathrm{NO}_{2}^{-}$maximum in the central-NE Arabian Sea OMZ, predominantly from $\mathrm{NO}_{3}^{-}$reduction, and to a certain extent ammonia oxidation in the upper OMZ. There was little evidence for $\mathrm{NO}_{2}^{-}$consumption via $\mathrm{N}$-loss as $\mathrm{N}_{2} \mathrm{O}$ or $\mathrm{N}_{2}$ production with only occasional, low potential rates; whereas $\mathrm{NO}_{2}^{-}$oxidation was predicted to be a major $\mathrm{NO}_{2}^{-}$sink. When the measured rates of all $\mathrm{NO}_{2}^{-}$sources and sinks were integrated over the thickness of the Arabian Sea OMZ, a small net production of $\mathrm{NO}_{2}^{-}\left(0.06 \mathrm{mmol} \mathrm{N} \mathrm{m}^{-2} \mathrm{~d}^{-1}\right)$ was calculated for the centralNE basin (Table 1A). This low rate is comparable with the net $\mathrm{NO}_{2}^{-}$production rates of $0.05 \pm 0.03 \mathrm{mmol} \mathrm{N} \mathrm{m}^{-2} \mathrm{~d}^{-1}$ (mean \pm standard deviation of 4 stations) estimated via reaction-diffusion flux modeling on $\mathrm{NO}_{2}^{-}$profiles (Table 1B). The slow build-up of the secondary $\mathrm{NO}_{2}^{-}$maximum corresponded with a general lack of modeled $\mathrm{N}$-loss rates from $\mathrm{N}^{*}$ profiles (Figs. 4 and A6d). Only at occasional depths in the central-NE OMZ were more severe $\mathrm{N}$-deficits produced (i.e. N-loss), reaching $2-4 \mathrm{nM} \mathrm{N} \mathrm{d}^{-1}$ according to modeled results. In fact, those were also the depths where potential $\mathrm{N}_{2}$ production rates of $1-2 \mathrm{nMN}_{2} \mathrm{~d}^{-1}$ (equivalent to $2-4 \mathrm{nM} \mathrm{N} \mathrm{d}^{-1}$; significantly greater than $0.15-0.20 \mathrm{nMd} \mathrm{d}^{-1}$, limits of detection) were measured via ${ }^{15} \mathrm{~N}$-incubation experiments, along with elevated anammox- and denitrifier nirS expression (Figs. 3, A2, A6).
In contrast, over the Omani shelf where the measured $\mathrm{N}$-loss rates were high, overall $\mathrm{NO}_{2}^{-}$production appeared to be exceeded by highly active $\mathrm{NO}_{2}^{-}$consumption (Table 1A). Considering the entire dataset for the Arabian Sea $\mathrm{OMZ}$, there was no significant correlation between $\mathrm{N}$-loss rates and $\mathrm{NO}_{2}^{-}$concentrations (Spearman rank-test, $p>$ 0.05). The most active N-loss (anammox) occurred at low to medium $\mathrm{NO}_{2}^{-}$levels, consistent with observations made for the Namibian and Peruvian OMZs (Kuypers et al., 2005; Hamersley et al., 2007; Lam and Kuypers, 2011). Consequently, the aptness of secondary $\mathrm{NO}_{2}^{-}$maximum as an indicator for active $\mathrm{N}$-loss in the OMZs becomes questionable.

$\mathrm{N}$-loss via anammox was directly coupled and significantly correlated with nitrate reduction (Spearman $\mathrm{R}=0.619$, $p<0.05$ ), DNRA (Spearman $\mathrm{R}=0.579, p<0.005$ ) and ammonia oxidation (Spearman $\mathrm{R}=0.556, p<0.0005$ ), whereas the concentration of $\mathrm{NO}_{2}^{-}$present in the water column was controlled by the dynamic balance among all these processes. Hence, it is unlikely for $\mathrm{NO}_{2}^{-}$to have a simple and direct relationship with $\mathrm{N}$-loss. When examining the regulation of N-loss, controlling factors for these other concurrent $\mathrm{N}$-cycling processes should also be taken into account. A multivariate multidimensional scaling analysis (final stress $=0.0633,5$ non-metric dimensions) on all of the rates, nutrients, gene abundance and expression data, not only confirmed the tight interdependence of these processes, but also revealed the strong associations of active N-loss with $\mathrm{NH}_{4}^{+}$, surface particulate organic carbon and nitrogen, as well as total microbial abundance and total RNA concentrations (active signals to generate proteins for various cellular reactions) (Fig. A7, Table B3). These associations 
implied an important role of organic matter in controlling microbial processes including N-loss. This is not surprising as both nitrate reduction and DNRA (and also denitrification, if present) are mainly heterotrophic processes that feed on organic matter, whereas ammonia oxidation and anammox, though both being lithoautotrophic processes, require $\mathrm{NH}_{4}^{+}$that needs to be remineralized from organic matter. The dependence of anammox on $\mathrm{NH}_{4}^{+}$was also apparent in the Arabian Sea (Spearman $\mathrm{R}=0.57, p<0.0001$ ) and other OMZs (Lam and Kuypers, 2011). In other words, Nloss and the coupling processes should be enhanced in more productive water columns. The scarcity of detectable active N-loss in the central-NE Arabian Sea OMZ would then be best explained by the low availability of labile organic matter sinking from the then quasi-oligotrophic surface waters (chlorophyll- $a \leq 0.2 \mathrm{mg} \mathrm{m}^{-3}$ ) (Fig. A8). Relative to the 10year record, surface chl- $a$ concentrations at the time of our sampling seemed rather representative for the central-NE basin, implying that our measurements of the subsequently affected $\mathrm{N}$-transformations were likely not far from the typical N-cycling activities in these waters (Fig. A8).

Nonetheless, if there was no consistent N-loss activity in the central-NE OMZ, how did the N-deficit therein become one of the largest in the world's Ocean? As N-deficit (or $\mathrm{N}^{*}$ ) is a time-integrated signal, it indicates the cumulative $\mathrm{N}$-loss that has occurred throughout the history of the water mass, and does not provide information on in situ N-loss activities. Large cumulative $\mathrm{N}$-deficits could have resulted from (1) consistently high N-loss in a water mass of short residence time, (2) episodically high $\mathrm{N}$-loss in a water mass of long residence time, or (3) consistently very low N-loss activities in an aged water mass. For the central-NE Arabian Sea OMZ, there is little consensus on the water residence time therein, with estimates ranging widely from 1.6 to 54 years (Sen Gupta et al., 1980; Naqvi, 1987; Somasundar and Naqvi, 1988; Olson et al., 1993). However, our hardly detectable N-loss rates at the time of our sampling could only be explained by scenarios (2) and (3), implying more likely a relatively high water residence time within the central-NE Arabian Sea OMZ. From the measured $\mathrm{NO}_{2}^{-}$inventory and modeled net $\mathrm{NO}_{2}^{-}$production rates through the $\mathrm{OMZ}(\sim 100$ $\left.1000 \mathrm{~m} ; \mathrm{O}_{2}<10 \mu \mathrm{M}\right), \mathrm{NO}_{2}^{-}$-turnover times were estimated to be $49 \pm 20$ years (mean \pm standard deviation of 4 stations) in the central-NE basin. Although these are not equivalent to water residence times, and the unaccounted horizontal advection would place the actual turnover times somewhat lower, the comparability between our measured and modeled $\mathrm{N}$ loss rate profiles strongly suggested that horizontal advective fluxes were not exceedingly high to support a much shorter residence time. Hence, high $\mathrm{NO}_{2}^{-}$in the central-NE OMZ is a tenable result of prolonged accumulation of slow net production, which is, in the long run, balanced by slow exchange with water outside the $\mathrm{OMZ}$, where $\mathrm{NO}_{2}^{-}$is eventually oxidized back to $\mathrm{NO}_{3}^{-}$. Meanwhile, the most negative $\mathrm{N}^{*}$ ob- served in the central-NE OMZ has likely included some degrees of severe $\mathrm{N}$-loss from basin boundaries, with additional low or episodic N-loss that occurs locally.

Surface primary production in the central-NE Arabian Sea is temporally and spatially patchy in nature, as nutrients are mainly delivered via mesoscale eddies spun off from boundary upwelling (Wiggert et al., 2005). Consequently, spatiotemporal heterogeneities are to be expected in N-cycling activities. Indeed, at the time of our sampling, temperature-salinity plots revealed different vertical structures in the water column at various stations and relative to archived data, with apparent signals of vertical mixing or upwelling only at St. 950 in the central-NE and over Omani shelf (Fig. A9). While most of our sampling times in the central-NE basin seemed representative with respect to the 10-year chl- $a$ record (compared to enhanced chl- $a$ at shelf stations that reflected residual influence of the SW monsoonal upwelling) (Fig. A8), unusually high chl- $a$ was recorded at St. 950 one week prior to our sampling but not two weeks before (Fig. A8c). Vertical stratification at St. 950 also seemed to have weakened during our sampling (Figs. $2 \mathrm{~h}$ and A9d). These data together strongly suggested the recent passing of an upwelling eddy that has stimulated an episodic algal bloom, and could explain the higher N-loss activity potentials measured at this station (Jensen et al., 2011). How frequent and to what degree these episodic events and mesoscale eddies occur may be deterministic to the overall nitrogen balance in this basin, and should be examined more closely.

\section{Conclusions}

In summary, the current study showed that at least at the time of our sampling, $\mathrm{NO}_{3}^{-}$-reduction was the most consistently active $\mathrm{N}$-cycling process in the central-NE Arabian Sea OMZ. Together with a small degree of ammonia oxidation (upper OMZ), they resulted in a net production and thus accumulation of $\mathrm{NO}_{2}^{-}$in this region. Active $\mathrm{NO}_{2}^{-}$ consumption via anammox, denitrification and DNRA were likely hampered directly or indirectly by the deficiency of labile organic matter in the central-NE Arabian Sea, leaving lithoautotrophic $\mathrm{NO}_{2}^{-}$-oxidation to $\mathrm{NO}_{3}^{-}$as the plausible major $\mathrm{NO}_{2}^{-}$-sink based on modeled calculations. This is not to say that reductive $\mathrm{NO}_{2}^{-}$consumption and active $\mathrm{N}$-loss never occur in the central-NE OMZ at all. Their activities therein are most probably low to undetectable in general, and may be intermitted with occasionally high rates during episodic algal blooms, for instance. A long water residence time could then have enabled the large accumulations of both $\mathrm{NO}_{2}^{-}$and $\mathrm{N}-$ deficits (Fig. 5), with the accumulated $\mathrm{NO}_{2}^{-}$eventually dissipated by slow water exchange and oxidized to $\mathrm{NO}_{3}^{-}$.

Our study has only captured a snapshot of the end of the 2007 SW monsoon, but biological production and subsequent downward fluxes of organic matter are also enhanced 
Shelf OMZ
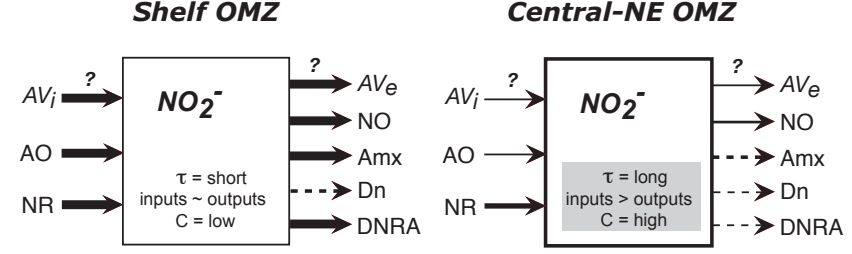

Fig. 5. A conceptual diagram illustrating that in the central-NE Arabian Sea OMZ, total $\mathrm{NO}_{2}^{-}$influx via $\mathrm{NO}_{3}^{-}$reduction $(\mathrm{NR})$ and to a lesser extent $\mathrm{NH}_{3}$ oxidation (AO), likely exceeds the combined $\mathrm{NO}_{2}^{-}$losses via mainly $\mathrm{NO}_{2}^{-}$oxidation (NO), and perhaps some low/intermittent (dashed arrows) anammox (Amx), dentrification (Dn) and dissimilatory nitrite reduction to ammonium (DNRA). The resultant slow accumulation, along with probably a long water residence time $(\tau)$, results in high $\mathrm{NO}_{2}^{-}$concentrations $(\mathrm{C})$ in the central-NE OMZ. In comparison, despite the apparently higher input rates detected over the shelf (thicker arrows of AO and NR), the similarly high outputs seem to roughly balance the high total inputs, thus maintaining a low $\mathrm{NO}_{2}^{-}$concentration in the shelf OMZ. Because no convincing evidence has been found to unambiguously confirm denitrification in the current study, this is shown here as dashed arrows to indicate its possible potentials only. Also shown in this diagram are the advective influxes $\left(\mathrm{AV}_{\mathrm{i}}\right)$ and outfluxes $\left(\mathrm{AV}_{\mathrm{e}}\right)$, which are postulated to be greater over shelf regions (thus shorter $\tau$ therein) than in the central-NE OMZ; but they have not been assessed in the current study (as indicated by “?").

during the NE monsoon in the Arabian Sea (Honjo et al., 1999; Wiggert et al., 2005). Further investigations are therefore imperative to assess $\mathrm{NO}_{2}^{-}$dynamics and $\mathrm{N}$-cycling during the NE monsoon, and to investigate possible seasonal variations throughout the year. However, as our sampling did take place at a time relatively representative of surface production in the central-NE Arabian Sea, our results show that the strong secondary $\mathrm{NO}_{2}^{-}$maximum is most likely a signature of an aged water mass with $\mathrm{NO}_{3}^{-}$-reducing conditions and has experienced past $\mathrm{N}$-loss but fails to result in much further in situ N-loss activity. This may also hold true for other major OMZs in the eastern tropical Pacific and Atlantic. Meanwhile, the near-shelf OMZ waters where in situ N-loss activities are high but $\mathrm{NO}_{2}^{-}$hardly accumulates, have rarely been included in global $\mathrm{N}$-budget estimates or model calculations. Consequently, previous $\mathrm{N}$-loss estimates based on few point-measurements extrapolating to large volumes of $\mathrm{NO}_{2}^{-}$-laden $\mathrm{OMZ}$ waters would be erroneous. For an accurate assessment of the $\mathrm{N}$-dynamics in the Arabian Sea and so its true significance in global N-balance, more interdisciplinary field and modeling studies of high spatiotemporal resolution should be extended to coastal regions, and the time and modes of ventilation from the shelves to the centralNE OMZ need to be more fully appraised. Our findings reemphasize the fact that $\mathrm{NO}_{2}^{-}$, being a dynamic intermediate, accumulates in the oceans because of a set of ill conditions (e.g. low availability of labile organic matter) that hinders further oxidation/reduction in the N-cycle. In the Arabian Sea OMZ and perhaps others, it is more likely the water upstream rather than right in the heart of secondary $\mathrm{NO}_{2}^{-}$maxima where high reductive $\mathrm{NO}_{2}^{-}$- consumption rates are to be expected, along with most other microbial processes.

\section{Supplementary material related to this article is available online at: http://www.biogeosciences.net/8/1565/2011/ bg-8-1565-2011-supplement.zip.}

Acknowledgements. We sincerely thank Gabriele Klockgether, Daniela Franzke, Stefanie Pietsch, Vera Meyer (MPI-MM), Birgit Gaye, Udo Huebner and Mark Metzke (University of Hamburg), as well as the captain and crew of R/V Meteor (M74/1b), for their conscientious technical and logistical support. We are also grateful to Rudolf Amann (MPI-MM) for the access to his laboratory facilities. Funding came from the Max Planck Gesellschaft, Deutsche Forschungsgemeinschaft (No. KU1550/3-1 for M. M. M. K and P. L.) and for Meteor cruise M74/1b), Danish Research Council (M. M. J.) and IFM-GEOMAR (A. K. and H. W. B.).

The service charges for this open access publication have been covered by the Max Planck Society.

Edited by: J. Middelburg

\section{References}

Altschul, S. F., Madden, T. L., Schäffer, A. A., Zhang, J., Zhang, Z., Miller, W., and Lipman, D. J.: Gapped BLAST and PSIBLAST: a new generation of protein database search programs, Nucl. Acids Res., 25, 3389-3402, 1997.

Bange, H. W., Rixen, T., Johansen, A. M., Siefert, R. L., Ramesh, R., Ittekkot, V., Hoffmann, M. R., and Andreae, M. O.: A revised nitrogen budget for the Arabian Sea, Global Biogeochem. Cycles, 14, 1283-1297, 2000.

Berg, P., Risgaard-Petersen, N., and Rysgaard, S.: Interpretation of measured concentration profiles in sediment pore water, Limnol. Oceanogr., 43, 1500-1510, 1998.

Bock, E., Wilderer, P. A., and Freitag, A.: Growth of Nitrobacter in the absence of dissolved oxygen, Water Res., 22, 245-250, 1988.

Brandhorst, W.: Nitrification and Denitrification in the Eastern Tropical North Pacific, ICES J. Mar. Sci., 25, 3-20, 1959.

Broecker, W. S.: "NO", a conservative water-mass tracer, Earth Planet. Sci. Lett., 23, 100-107, 1974.

Bulow, S. E., Rich, J. J., Naik, H. S., Pratihary, A. K., and Ward, B. B.: Denitrification exceeds anammox as a nitrogen loss pathway in the Arabian Sea oxygen minimum zone, Deep-Sea Res. Pt. I, 57, 384-393, 2010.

Capone, D. G., Subramaniam, A., Montoya, J. P., Voss, M., Humborg, C., Johansen, A. M., Siefert, R. L., and Carpenter, E. J.: An extensive bloom of the N-2-fixing cyanobacterium Trichodesmium erythraeum in the central Arabian Sea, Mar. Ecol. Prog. Ser., 172, 281-292, 1998. 
Cline, J. D. and Richards, F. A.: Oxygen Deficient Conditions and Nitrate Reduction in the Eastern Tropical North Pacific Ocean, Limnol. Oceanogr., 17, 885-900, 1972.

Codispoti, L. A. and Packard, T. T.: Denitrification rates in the eastern tropical South-Pacific, J. Mar. Res., 38, 453-477, 1980.

Codispoti, L. A. and Christensen, J. P.: Nitrification, denitrification and nitrous oxide cycling in the eastern tropical South Pacific ocean, Mar. Chem., 16, 277-300, 1985.

Codispoti, L. A., Friederich, G. E., Packard, T. T., Glover, H. E., Kelly, P. J., Spinrad, R. W., Barber, R. T., Elkins, J. W., Ward, B. B., Lipschultz, F., and Lostaunau, N.: High nitrite levels off northern Peru - a signal of instability in the marine denitrification rate, Science, 233, 1200-1202, 1986.

Codispoti, L. A., Brandes, J. A., Christensen, J. P., Devol, A. H., Naqvi, S. W. A., Paerl, H. W., and Yoshinari, T.: The oceanic fixed nitrogen and nitrous oxide budgets: Moving targets as we enter the anthropocene?, Sci. Mar., 65, 85-105, 2001.

Dalsgaard, T., Canfield, D. E., Petersen, J., Thamdrup, B., and Acuña-González, J.: $\mathrm{N}_{2}$ production by the anammox reaction in the anoxic water column of Golfo Dulce, Costa Rica, Nature, 422, 606-608, 2003.

Deutsch, C., Sarmiento, J. L., Sigman, D. M., Gruber, N., and Dunne, J. P.: Spatial coupling of nitrogen inputs and losses in the ocean, Nature, 445, 163-167, 2007.

Devol, A. H., Uhlenhopp, A. G., Naqvi, S. W. A., Brandes, J. A., Jayakumar, D. A., Naik, H., Gaurin, S., Codispoti, L. A., and Yoshinari, T.: Denitrification rates and excess nitrogen gas concentrations in the Arabian Sea oxygen deficient zone, Deep-Sea Res. Pt. I, 53, 1533-1547, 2006.

Dore, J. E. and Karl, D. M.: Nitrification in the euphotic zone as a source for nitrite, nitrate, and nitrous oxide at Station ALOHA, Limnol. Oceanogr., 41, 1619-1628, 1996.

Farrenkopf, A. M., Dollhopf, M. E., Chadhain, S. N., Luther, G. W., and Nealson, K. H.: Reduction of iodate in seawater during Arabian Sea shipboard incubations and in laboratory cultures of the marine bacterium Shewanella putrefaciens strain MR-4, Mar. Chem., 57, 347-354, 1997.

Fennel, K. and Boss, E.: Subsurface maxima of phytoplankton and chlorophyll: Steady-state solutions from a simple model, Limnol. Oceanogr., 48, 1521-1534, 2003.

Fiadeiro, M. and Strickland, J. D. H.: Nitrate reduction and the occurrence of a deep nitrite maximum in the ocean off the west coast of South America, J. Mar. Res., 26, 187-201, 1968.

Gargett, A. E.: Vertical eddy diffusivity in the ocean interior, J. Mar. Res., 42, 359-393, 1984.

Gilson, H. C.: The nitrogen cycle, in: The John Murray Expedition, 1933-1934, Scientific Reports, edited by: Gilson, H. C., British Museum (Natural History), London, 21-81, 1937.

Grasshoff, K.: Determination of nitrite, in: Methods in seawater analyse, edited by: Grasshoff, K., Ehrhardt, M., and Kremling, K., Wiley-VCH, 1983.

Grasshoff, K., Ehrhardt, M., Kremling, K., and Anderson, L. G.: Methods of seawater analysis, Wiley, 1999.

Gregg, M. C., D’Asaro, E. A., Shay, T. J., and Larson, N.: Observations of Persistent Mixing and Near-Inertial Internal Waves, J. Phys. Oceanogr., 16, 856-885, 1986.

Griffin, B. M., Schott, J., and Schink, B.: Nitrite, an Electron Donor for Anoxygenic Photosynthesis, Science, 316, 1870 pp., 2007.

Gruber, N.: The marine nitrogen cycle: overview and challenges, in: Nitrogen in the Marine Environment, edited by: Capone, D. G., Bronk, D. A., Mulholland, M. R., and Carpenter, E. J., Elsevier Inc., 1-50, 2008.

Gruber, N. and Sarmiento, J. L.: Global patterns of marine nitrogen fixation and denitrification, Glob. Biogeochem. Cycles, 11, 235266, 1997.

Hamersley, M. R., Lavik, G., Woebken, D., Rattray, J. E., Lam, P., Hopmans, E. C., Damste, J. S. S., Kruger, S., Graco, M., Gutierrez, D., and Kuypers, M. M. M.: Anaerobic ammonium oxidation in the Peruvian oxygen minimum zone, Limnol. Oceanogr., 52, 923-933, 2007.

Hollocher, T. C.: Source of the oxygen atoms of nitrate in the oxidation of nitrite by Nitrobacter agilis and evidence against a $\mathrm{P}$ $\mathrm{O}-\mathrm{N}$ anhydride mechanism in oxidative phosphorylation, Arch. Biochem. Biophys., 233, 721-727, 1984.

Holmes, R. M., Aminot, A., Kerouel, R., Hooker, A., and Peterson, B. J.: A simple and precise method for measuring ammonium in marine and freshwater ecosystems, Can. J. Fish Aqaut. Sci., 56, 1801-1808, 1999.

Honjo, S., Dymond, J., Prell, W., and Ittekkot, V.: Monsooncontrolled export fluxes to the interior of the Arabian Sea, DeepSea Res. Pt. II, 46, 1859-1902, 1999.

Jackett, D. R. and McDougall, T. J.: A neutral density variable for the world's oceans, J. Phys. Oceanogr., 27, 237-263, 1997.

Jensen, M. M., Kuypers, M. M. M., Lavik, G., and Thamdrup, B.: Rates and regulation of anaerobic ammonium oxidation and denitrification in the Black Sea, Limnol. Oceanogr., 53, 23-36, 2008.

Jensen, M. M., Lam, P., Revsbech, N. P., Nagel, B., Gaye, B., Jetten, M. S. M., and Kuypers, M. M. M.: Intensive nitrogen loss over the Omani Shelf due to anammox coupled with dissimilatory nitrite reduction to ammonium, ISME J., doi:10.1038/ismej.2011.44, 2011.

Kumar, S., Nicholas, D. J. D., and Williams, E. H.: Definitive $15 \mathrm{~N}$ NMR evidence that water serves as a source of "O" during nitrite oxidation by Nitrobacter agilis, FEBS Letters, 152, 71-74, 1983.

Kuypers, M. M. M., Lavik, G., Woebken, D., Schmid, M., Fuchs, B. M., Amann, R., Jorgensen, B. B., and Jetten, M. S. M.: Massive nitrogen loss from the Benguela upwelling system through anaerobic ammonium oxidation, Proc. Natl. Acad. Sci. USA, 102, 6478-6483, 2005.

Lam, P. and Kuypers, M. M. M.: Microbial Nitrogen Cycling Processes in Oxygen Minimum Zones, Ann. Rev. Mar. Sci., 3, 317345, 2011.

Lam, P., Lavik, G., Jensen, M. M., van de Vossenberg, J., Schmid, M., Woebken, D., Gutierrez, D., Amann, R., Jetten, M. S. M., and Kuypers, M. M. M.: Revising the nitrogen cycle in the Peruvian oxygen minimum zone, Proc. Natl. Acad. Sci. USA, 106, 4752-4757, 2009.

Lettmann, K. A., Riedinger, N., Ramlau, R., Knab, N., Böttcher, M. E., Khalili, A., Wolff, J.-O., and Jørgensen, B. B.: Estimation of biogeochemical rates from concentration profiles: A novel inverse method, Estuar. Coast. Shelf Sci., doi:10.1016/j.ecss.2011.01.012, 2011.

Lewis, B. L. and Luther, G. W., III.: Processes controlling the distribution and cycling of manganese in the oxygen minimum zone of the Arabian Sea, Deep-Sea Res. Pt. II, 47, 1541-1561, 2000.

Lipschultz, F., Wofsy, S. C., Ward, B. B., Codispoti, L. A., Friedrich, G., and Elkins, J. W.: Bacterial transformations of inorganic nitrogen in the oxygen-deficient waters of the Eastern 
Tropical South Pacific Ocean, Deep-Sea Res., 37, 1513-1541, 1990.

Lomas, M. W. and Lipschultz, F.: Forming the primary nitrite maximum: nitrifiers or phytoplankton? Limnol. Oceanogr., 51, 2453 2467, 2006.

Ludwig, W., Strunk, O., Westram, R., Richter, L., Meier, H., Yadhukumar, Buchner, A., Lai, T., Steppi, S., Jobb, G., Förster, W., Brettske, I., Gerber, S., Ginhart, A. W., Gross, O., Grumann, S., Hermann, S., Jost, R., König, A., Liss, T., Lüßmann, R., May, M., Nonhoff, B., Reichel, B., Strehlow, R., Stamatakis, A. P., Stuckmann, N., Vilbig, A., Lenke, M., Ludwig, T., Bode, A., and Schleifer, K.-H.: ARB: a software environment for sequence data, Nucl. Acids Res., 32, 1363-1371, 2004.

McIlvin, M. R. and Altabet, M. A.: Chemical Conversion of Nitrate and Nitrite to Nitrous Oxide for Nitrogen and Oxygen Isotopic Analysis in Freshwater and Seawater, Anal. Chem., 77, 55895595, 2005.

Moffett, J. W., Goepfert, T. J., and Naqvi, S. W. A.: Reduced iron associated with secondary nitrite maxima in the Arabian Sea, Deep-Sea Res. Pt. I, 54, 1341-1349, 2007.

Morrison, J. M., Codispoti, L. A., Smith, S. L., Wishner, K., Flagg, C., Gardner, W. D., Gaurin, S., Naqvi, S. W. A., Manghnani, V., Prosperie, L., and Gundersen, J. S.: The oxygen minimum zone in the Arabian Sea during 1995, Deep Sea Res. Pt. II, 46, 1903 1931, 1999.

Naqvi, S. W. A.: Some aspects of the oxygen-deficient conditions and denitrification in the Arabian Sea, J. Mar. Res., 45, 10491072, 1987.

Naqvi, S. W. A.: Geographical extent of denitrification in the Arabian Sea in relation to some physical processes, Oceanol. Acta, 14, 281-290, 1991.

Naqvi, S. W. A., Noronha, R. J., Somasundar, K., and Sen Gupta, R.: Seasonal changes in the denitrification regime of the Arabian Sea, Deep Sea Res. Pt. A, 37, 593-611, 1990.

Nicholls, J. C., Davies, C. A., and Trimmer, M.: High-resolution profiles and nitrogen isotope tracing reveal a dominant source of nitrous oxide and multiple pathways of nitrogen gas formation in the central Arabian Sea, Limnol. Oceanogr., 52, 156-168, 2007.

Olson, D. B., Hitchcock, G. L., Fine, R. A., and Warren, B. A.: Maintenance of the low-oxygen layer in the central Arabian Sea, Deep-Sea Res. Pt. II, 40, 673-685, 1993.

Olson, R. J.: ${ }^{15} \mathrm{~N}$ tracer studies of the primary nitrite maximum, J. Mar. Res., 39, 203-226, 1981.

Poth, M. and Focht, D. D.: ${ }^{15} \mathrm{~N}$ Kinetic analysis of $\mathrm{N}_{2} \mathrm{O}$ production by Nitrosomonas euraea: an examination of nitrifier denitrification, Appl. Environ. Microbiol., 49, 1134-1141, 1985.

Revsbech, N. P., Larsen, L. H., Gundersen, J. K., Dalsgaard, T., Ulloa, O., and Thamdrup, B.: Determination of ultra-low oxygen concentrations in oxygen minimum zones by the STOX sensor., Limnol. Oceanogr.-Meth., 7, 371-381, 2009.

Ritchie, G. A. F. and Nicholas, D. J. D.: Identification of nitrous oxide produced by oxidative and reductive processes in Nitrosomonas europaea., Biochem. J., 126, 1181-1191, 1972.
Sen Gupta, R., Braganca, A., Noronha, R. J., and Singbal, S. S. S.: Chemical oceanography of the Arabian Sea: Part V - Hydrochemical characteristics on the central west coast of India, Indian J. Mar. Sci., 9, 240-245, 1980.

Somasundar, K. and Naqvi, S. W. A.: On the renewal of the denitrifying layer in the Arabian Sea, Oceanol. Acta, 11, 167-172, 1988.

Strous, M., Pelletier, E., Mangenot, S., Rattei, T., Lehner, A., Taylor, M. W., Horn, M., Daims, H., Bartol-Mavel, D., Wincker, P., Barbe, V. R., Fonknechten, N., Vallenet, D., Segurens, B. A., Schenowitz-Truong, C., Médigue, C., Collingro, A., Snel, B., Dutilh, B. E., Op den Camp, H. J. M., van der Drift, C., Cirpus, I., van de Pas-Schoonen, K. T., Harhangi, H. R., van Niftrik, L., Schmid, M., Keltjens, J., van de Vossenberg, J., Kartal, B., Meier, H., Frishman, D., Huynen, M. A., Mewes, H.-W., Weissenbach, J., Jetten, M. S. M., Wagner, M., and Le Paslier, D.: Deciphering the evolution and metabolism of an anammox bacterium from a community genome, 440, 790-794, 2006.

Thamdrup, B., Dalsgaard, T., Jensen, M. M., Ulloa, O., Farías, L., and Escribano, R.: Anaerobic ammonium oxidation in the oxygen-deficient waters off northern Chile, Limnol. Oceanogr., 51, 2145-2156, 2006.

Trouwborst, R. E., Clement, B. G., Tebo, B. M., Glazer, B. T., and Luther, G. W., III: Soluble Mn(III) in Suboxic Zones, Science, 313, 1955-1957, 2006.

van de Graaf, A. A., Mulder, A., de Bruijn, P., Jetten, M. S. M., and Kuenen, J. G.: Anaerobic oxidation of ammonium is a biologically mediated process, Appl. Environ. Microbiol., 61, 12461251, 1995.

van de Graaf, A. A., de Bruijn, P., Robertson, L. A., Jetten, M. S. M., and Kuenen, J. G.: Metabolic pathway of anaerobic ammonium oxidation on the basis of N-15 studies in a fluidized bed reactor, Microbiology, 143, 2415-2421, 1997.

Van Mooy, B. A. S., Keil, R. G. and Devol, A. H.: Impact of suboxia on sinking particulate organic carbon: Enhanced carbon flux and preferential degradation of amino acids via denitrification, Geochim. Cosmochim. Acta, 66, 457-465, 2002.

Walter, S., Bange, H. W., Breitenbach, U., and Wallace, D. W. R.: Nitrous oxide in the North Atlantic Ocean, Biogeosciences, 3, 607-619, 2006, http://www.biogeosciences.net/3/607/2006/.

Ward, B. B., Devol, A. H., Rich, J. J., Chang, B. X., Bulow, S. E., Naik, H., Pratihary, A., and Jayakumar, A.: Denitrification as the dominant nitrogen loss process in the Arabian Sea, Nature, 461, 78-81, 2009.

Wiggert, J. D., Hood, R. R., Banse, K., and Kindle, J. C.: Monsoondriven biogeochemical processes in the Arabian Sea, Prog. Oceanogr., 65, 176-213, 2005.

Wooster, W. S., Chow, T. J., and Barret, I.: Nitrite distribution in Peru current waters, J. Mar. Res., 23, 210-221, 1965.

You, Y. and McDougall, T. J.: Neutral surfaces and potential vorticity in the worlds oceans, J. Geophys. Res., 95, 13235-13261, 1990. 